\title{
Process Diagnosis and Aging Effects on a Traditional Millet-Based Drink: Boumkaye
}

\author{
Oumar Ibn Khatab Cisse ${ }^{1,2}$, Nicolas Cyrille Ayessou ${ }^{1,2 *}$, Papa Guedel Faye ${ }^{1,2}$, Mady Cisse ${ }^{1,2}$, \\ Aida Coly Camara3 , Aba Bodian4, Cheikh Ndiayes, Mama Sakho, ${ }^{1,2}$, Codou Mar Diop ${ }^{1,2}$ \\ ${ }^{1}$ Ecole Supérieure Polytechnique, Cheikh Anta Diop University, Dakar, Sénégal \\ ${ }^{2}$ Centre d'Etudes sur la Sécurité Alimentaire et les Molécules Fonctionnelles (CESAM), Dakar, Sénégal \\ ${ }^{3}$ Entreprise AFBARD, Dakar, Sénégal \\ ${ }^{4}$ Producteur de Boumkaye originaire de Baïla, Dakar, Sénégal \\ ${ }^{5}$ Institut de technologie alimentaire (ITA) Dakar, Sénégal \\ Email: cisse87oumar@hotmail.com, ^nayessou@yahoo.fr, guedougui@hotmail.com,mady.cisse@ucad.edu.sn, \\ checknd@hotmail.com,mfsakho@yahoo.fr,cgmare@gmail.com
}

How to cite this paper: Cisse, O.I.K. Ayessou, N.C., Faye, P.G., Cisse, M., Camara, A.C., Bodian, A., Ndiaye, C., Sakho, M. and Diop, C.M. (2018) Process Diagnosis and Aging Effects on a Traditional Millet-Based Drink: Boumkaye. Food and Nutrition Sciences, 9, 464-473. https://doi.org/10.4236/fns.2018.95036

Received: March 12, 2018

Accepted: May 14, 2018

Published: May 17, 2018

Copyright $\odot 2018$ by authors and Scientific Research Publishing Inc. This work is licensed under the Creative Commons Attribution International License (CC BY 4.0).

http://creativecommons.org/licenses/by/4.0/

\begin{abstract}
Boumkaye is a traditional fermented millet-based drink (Pennisetum glaucum L.) produced in Casamance (region in Senegal). Unknown and circumcised beverage, it has therapeutic properties due to aqueous creeper extracts from Abrus pulchellus plant and naturally present during the process. The objective of this work was to investigate the fabrication process of a millet-based beverage as an alternative source of nutrients. The diagnosis of beverage production by monitoring its physical and chemical parameters during two months of storage at room temperature was studied. The established manufacturing process, composed by a production of aqueous extracts after maceration of the Abrus pulchellus vines, a preparation of millet slurry, and a fermentation step to obtain the Boumkaye, has several features. The study of aging process showed probable lactic and alcoholic fermentations. Further, the finished Boumkaye was characterized by a high acidity ( $\mathrm{pH}$ of 3 ), an alcohol content of $5 \mathrm{~g} / 100 \mathrm{~g}$ and contains an appreciable amount of polyphenols $(54.46 \mathrm{mg} / 100 \mathrm{~g})$.
\end{abstract}

\section{Keywords}

Pennisetum glaucum L., Abrus pulchellus, Traditional Drinks, Fermentation, Boumkaye

\section{Introduction}

In Africa, many traditional beers are especially prepared from millet, sorghum, 
rice and maize [1] [2]. These drinks are used in many cultural and social events showing hospitality and conviviality in lifestyle of most families. They are also used to strengthen relationships between individuals [3] [4]. Different reactions are initiated during the manufacture of traditional African beers, and usually continue until consumption according to empirical processes. In Casamance region (South of Senegal), a fermented drink called Boumkaye is considered to possess anthelmintic virtues related to aqueous extracts from the plant of Abrus pulchellus. Abrus pulchellus is a medicinal plant known for its many uses in traditional medicine for its pharmacological and anticancer properties, also to treat gastric problems [5] [6]. Despite its sociological importance in this southern zone of Senegal, the fabrication process of a traditional beer with Abrus pulchelIus extracts has not previously been reported. In addition, ethnobotanical studies (Reference) revealed that many properties of Boumkaye drink were obtained during aging process. Therefore, the objective of this present study was to thoroughly investigate the manufacturing process of Boumkaye and its aging on physico- and biochemical changes that would explain traditional benefits previously mentioned. This would help to facilitate a large-scale production of this traditional fermented millet based beverage.

\section{Materials and Methods}

\subsection{Diagnosis of Manufacturing Processes}

Two production sites, AFBARD Company and traditional Baila producers, were used in monitoring and diagnosing manufacturing of Boumkaye variability in the period of May to July.

Each operation unit was identified and described. Material flows and physical parameters were listed. In the sites, information was supplemented by observations, recordings (temperature, time), measurements (weight, volume), and interviews with different operators. The process description was performed twice in each production site. The same conditions were used in laboratory in order to similarly reproduce the fermented studied drink for the aging study.

\subsection{Plant Material}

The analyzed samples of Boumkaye drinks were obtained during the diagnoses. Boumkaye 1 was produced following AFBARD Company procedure; while Boumkaye 2 drinks was obtained as described in traditionally produced by Baila producers. Two samples per site were analyzed. Analyses of each were performed in triplicate.

\subsection{Analytical Methods}

The $\mathrm{pH}$, titratable acidity, dry matter, and the ethanol content were evaluated according to the AFNOR standard methods [7]. The reducing sugars and total 
sugars were quantified by Luff Schoorl's method [7]. Total polyphenols were determined according to George method, in Gallic acid equivalent [8].

\subsection{Statistical Analysis}

The analysis of variance (ANOVA) tests on each factor were carried out with the STATISTICA 7.1 software. The objective was to compare significance of samples' analytical results for each parameter. Statistical differences with a probability value less than $0.05(\mathrm{P}<0.05)$ were considered as significant.

\subsection{Aging Study of the Fermented Drinks}

The aging study was followed by monitoring and characterizing the evolution of parameters during the storage and/or manufacturing conditions. The crude Boumkaye obtained at the end of each diagnosis was kept at ambient temperature $\left(25^{\circ} \mathrm{C}\right)$. A monitoring period of 7 days was carried out on each sample batch physicochemical and biochemical parameters during one month storage.

\section{Results and Discussion}

\subsection{The Manufacturing Process}

A production diagram was made following both studied sites. Thus, three different parts including the production of an aqueous extract by maceration of the creepers of Abrus pulchellus (Figure 1 and Figure 2); the preparation of the millet slurry and a final fermentation step to obtain the Boumkaye (Figure 3).

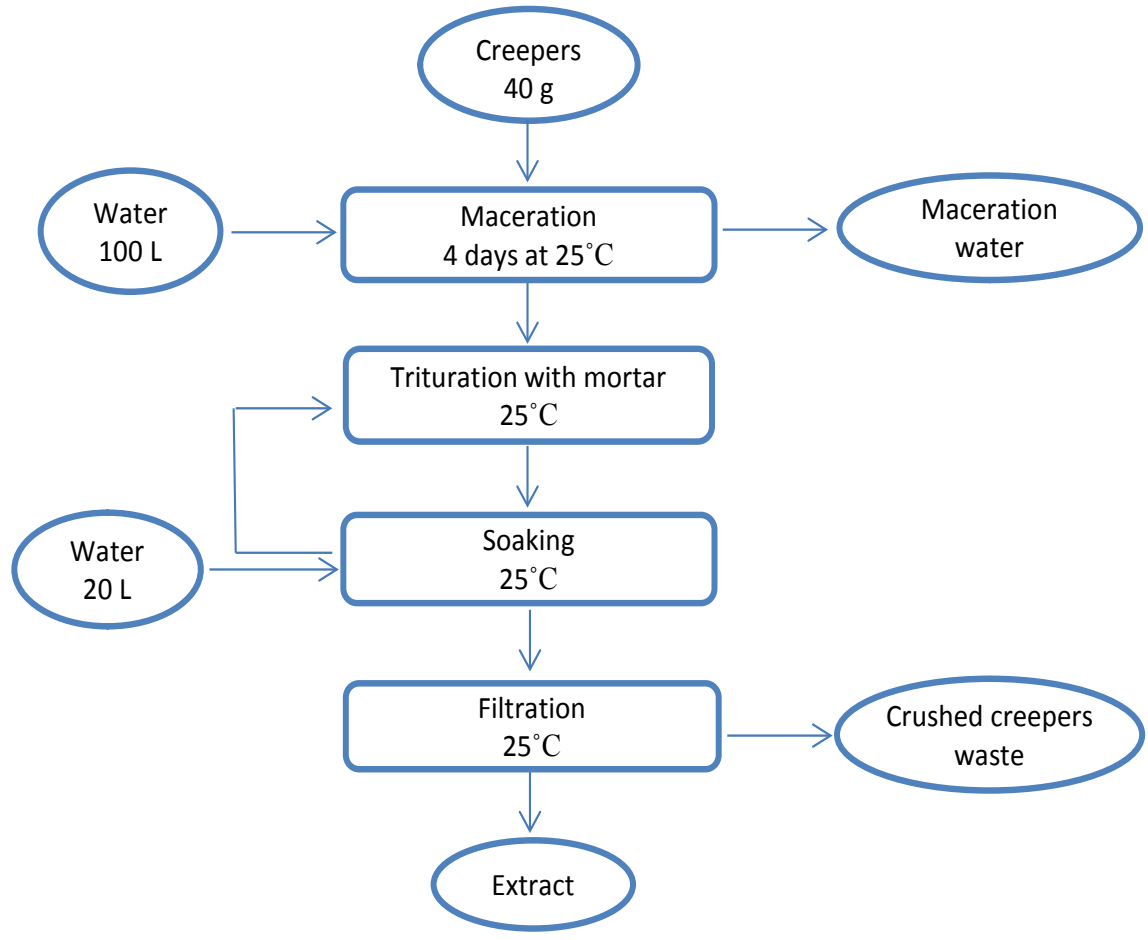

Figure 1. Diagram for obtaining the aqueous extract of the creepers of Abrus pulchellus. 


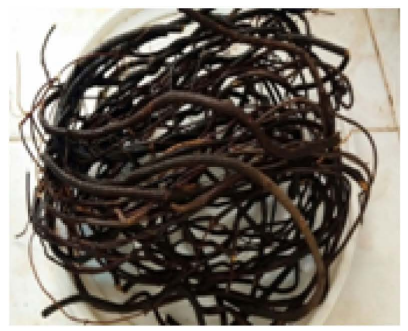

(a)

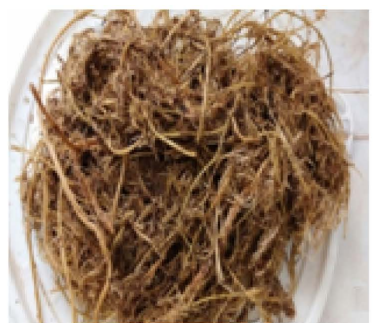

(b)

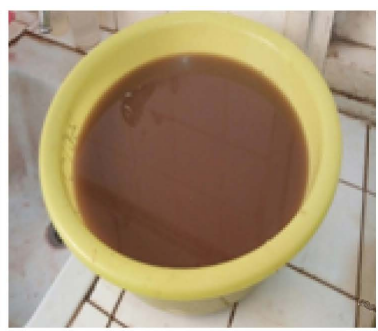

(c)

Figure 2. The creepers of Abrus pulchellus before (a) and after (b) trituration-soaking and aqueous extract (c).

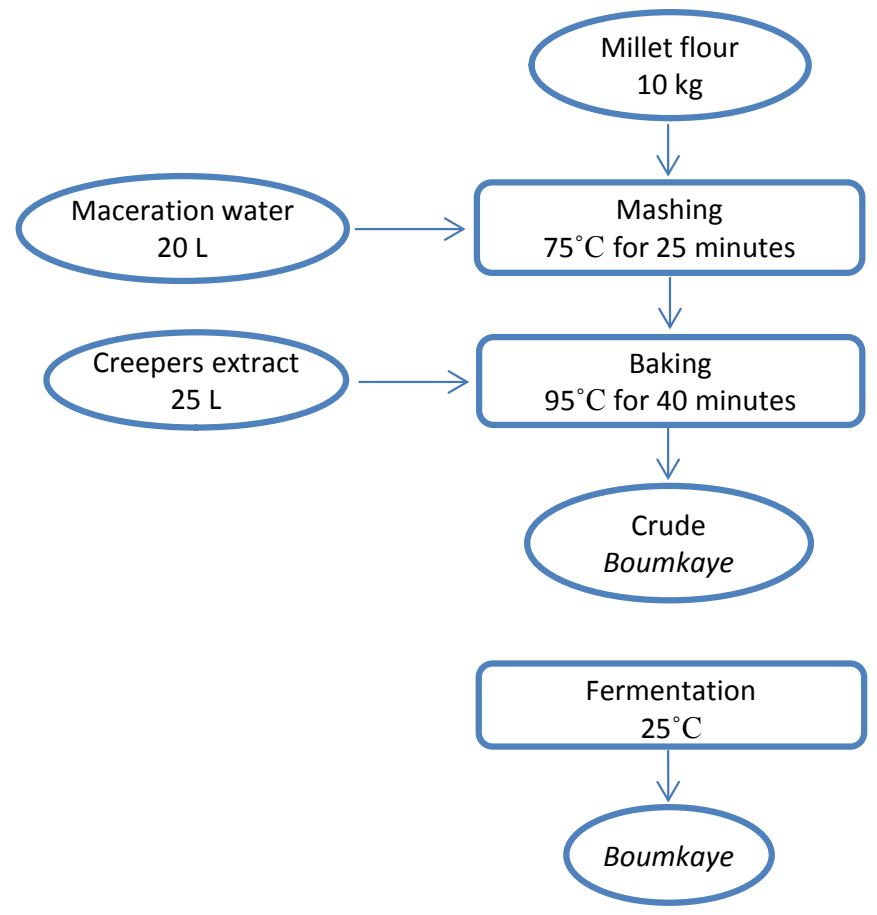

Figure 3. Boumkaye's production diagram.

\subsubsection{The Aqueous Extract of Abrus pulchellus}

Three to four days of maceration in water of Abrus pulchellus creepers (Figure 2(a)) was done in order to soften and facilitate active ingredients' extraction. The softened lianas were then triturated with mortar in a controlled manner and then soaked in a basin of water. This operation was repeated several times in order to remove sufficiently the bark (Figure 2(b)). The extract was then filtered and the slurry was used in the next step of fermentation (Figure 2(c)).

\subsubsection{Preparation of the Mixture and Fermentation Steps for Boumkaye Obtention}

The millet flour was mixed with water from macerated Abrus pulchellus creepers in a ratio of $10 \mathrm{~kg} / 20 \mathrm{~L}$ (w:v) during a first cooking phase which lasts 25 to 30 minutes. In this period, a paste was formed and the dough was brought to a maximum temperature of $75^{\circ} \mathrm{C}$. A second cooking phase was initiated after adding 25 liters of extract of the Abrus pulchellus creepers. The cooking was 
carried out at $95^{\circ} \mathrm{C}$ for 40 minutes to obtain a crude Boumkaye which can be consumed. Furthermore, this intermediate product was stored at room temperature $\left(\ldots . .{ }^{\circ} \mathrm{C}\right)$ for (....) days, which allowed a fermentation step for the final Boumkaye.

Stages of malting, brewing and fermentation are the main components used in traditional (Tchapalo, Dolo) and industrial processes. The purpose of mixing was to solubilize the bioactive compounds and to produce lytic enzymes necessary for the production of fermentable sugars [9], while the fermentation takes place after adding leaven.

The manufacturing process for producing Boumkaye beverage is different and presents particular features different to malting, a brewing step without separation of the grains and the use of aqueous extracts of vegetable origin. The creepers of $A$. pulchellus underwent a maceration step which help softening and facilitating the trituration step. The trituration-soaking step could represent the actual extraction phase of the active compounds required during the production of Boumkaye. The paste formation was involved in the hydrolysis phase of the starch contained in the millet flour. It was carried out hot for enabling the activation of various enzymes, responsible of the starch conversion into simple fermentable sugars. Thus, Boumkaye could maintain most ingredients (nutrients and fibers) of the millet flours, and therefore constitute a real food rather than a drink. The cooking time was also reduced compared to the Tchapalo and Dolo process [10] [11]. A natural fermentation of the slurry at room temperature without adding ferments was performed. Therefore, a phase of aging was necessary where the drink acquired most of its characteristic organoleptic properties. These various biotransformations would probably be initiated by germs either endogenous to millet or derived from the extract of the creepers of Abrus pulchellus. In the case of Tchapalo and Dolo, extracts of okra stems Hibiscus esculentus are used [12]. It was tempted to deduce that the stirring step was carried out by the aqueous extract of $A$. pulchellus. This would imply the presence of hydrolytic enzymes in this extract.

\subsection{Physico-Chemical Characteristics of the Raw Boumkaye}

The Boumkaye drinks obtained during the diagnoses were subjected to physico-chemical, biochemical and nutritional characterizations. Results are presented in Table 1 . Products $\mathrm{pH}$ was around 4 in the extracts millet based and titratable acidities were ranged from 1.62 to $3.4 \mathrm{mEq} / 100 \mathrm{~g}$. These results proved that the beverages were relatively non-acidic, and very favorable to the different fermentation reactions. The two production trials on Boumkaye revealed significant differences in the values with exception of polyphenols, dry matter and minerals.

\subsection{Study of the Aging}

The samples collected after the diagnosis were stored at room temperature $\left(30^{\circ} \mathrm{C}\right)$. 
Table 1. Physico-chemical and biochemical characteristics of the raw Boumkaye.

\begin{tabular}{ccc}
\hline Analyzes & Boumkaye 1 & Boumkaye 2 \\
\hline Dry matter $(\mathrm{g} / 100 \mathrm{~g})$ & $9.84 \pm 0.07^{\mathrm{a}}$ & $11.47 \pm 0.01^{\mathrm{b}}$ \\
Ash $(\mathrm{g} / 100 \mathrm{~g})$ & $0.69 \pm 0.19^{\mathrm{a}}$ & $0.88 \pm 0.19^{\mathrm{a}}$ \\
$\mathrm{pH}$ & $4.62 \pm 0.13^{\mathrm{a}}$ & $4.26 \pm 0.00^{\mathrm{b}}$ \\
Titratable acidity $(\mathrm{mEq} / 100 \mathrm{~g})$ & $1.62 \pm 0.17^{\mathrm{a}}$ & $3.40 \pm 0.20^{\mathrm{b}}$ \\
Polyphenols (mg galic acid/100g) & $31.86 \pm 0.01^{\mathrm{a}}$ & $54.46 \pm 0.01^{\mathrm{a}}$ \\
Reducing sugars $(\mathrm{g} / 100 \mathrm{~g})$ & $0.94 \pm 0.00^{\mathrm{a}}$ & $1.90 \pm 0.22^{\mathrm{b}}$ \\
Total sugars $(\mathrm{g} / 100 \mathrm{~g})$ & $1.04 \pm 0.00^{\mathrm{a}}$ & $2.10 \pm 0.02^{\mathrm{b}}$ \\
Protein $(\mathrm{g} / 100 \mathrm{~g})$ & $2.39 \pm 0.00^{\mathrm{a}}$ & $10.37 \pm 0.00^{\mathrm{b}}$ \\
\hline
\end{tabular}

The analyzed parameters were related to fermentation reactions and the aging of Boumkaye. Thus, pH (Figure 4), titratable acidity (Figure 5) and ethanol content (Figure 6) were followed in several batches of Boumkaye crude. The values obtained from studied products reflected a lower $\mathrm{pH}$ (how much?). This $\mathrm{pH}$ value could be explained by sugars consumption through the fermentation process. During the aging, increase of acid contents could be explained by a lactic fermentation, a conversion of reducing sugars into acids (Figure 5). At the same time, an alcoholic fermentation took place, explaining the increase of alcohol content (average of $5 \mathrm{~g} / 100 \mathrm{~g}$ ) (Figure 6).

Many reactions occur during fermentation resulting of a decrease of reducing sugars. The consumption was reflected in decrease of $\mathrm{pH}$ during aging (maturation), due to combined effects of ethanol and organic acids. The $\mathrm{pH}$ firstly exerts a selective action on the microflora likely to develop in the medium. The increase of low $\mathrm{pH}$ protects the beverage from the development of any pathogenic flora without inhibiting the activity of the yeast. In addition, some authors stated that an important inhibition would occur at a very acidic $\mathrm{pH}$ (pH below 3) [13] [14]. Consequently, the decrease in $\mathrm{pH}$ by a production of fermented products (acid or alcohol) reduced the consumption rate of the carbonaceous substrate (reducing sugars) and consequently reduces productivity [10]. Therefore, ethanol becomes toxic to microorganisms beyond a certain value. This justifies the limiting $\mathrm{pH}$ of Boumkaye 3 found mostly in traditional African drinks [11] [15] [16] [17], unlike industrial beers which contain hops [18]. Two types of traditional beers were found according to composition and appearance during the sensory evaluation. These could be ranged from sweet, relatively light, non-acid with little material and acid beers, brown and opaque, resembling fluid porridge. The main difference between these two categories of beer was related to the duration of lactic fermentation [19]. Also, work on Rwandan Ikigage showed beneficial influence of the yeast from Saccharomyces cerevisiae species and lactic acid bacteria (Lactobacillus fermentum) on taste and aroma [20]. While in Ivorian Tchapalo, the production of bacteriocins by lactic acid bacteria inhibits the development and growth of many pathogenic germs of the genus 


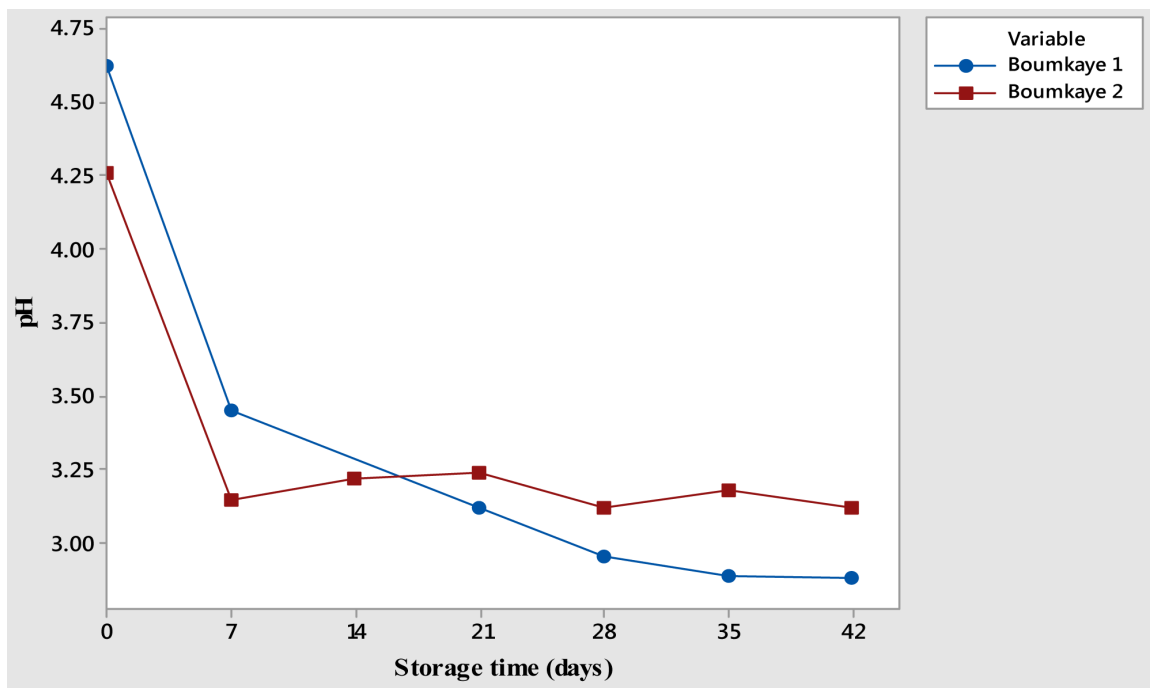

Figure 4. Evolution of the $\mathrm{pH}$ during the maturation of Boumkaye.

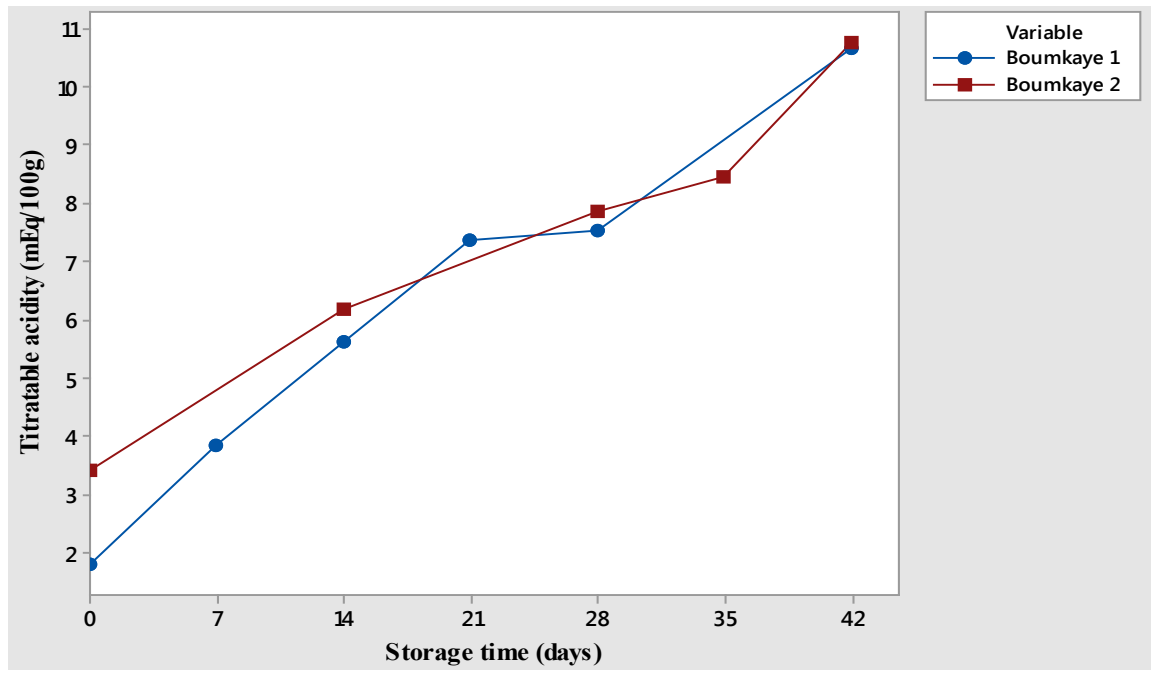

Figure 5. Evolution of the titratable acidity during maturation of Boumkaye.

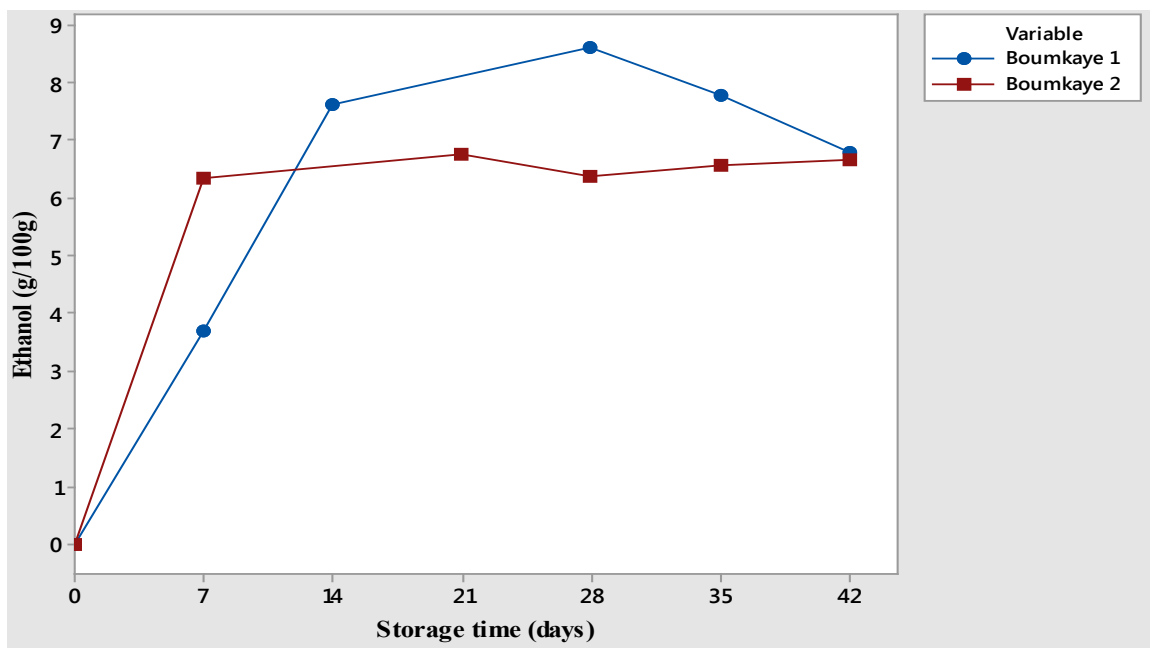

Figure 6. Evolution of the ethanol content during the maturation of Boumkaye. 
Lactobacillus, Listeria, Enterococcus, Streptococcus [21]. The fermented Boumkaye was characterized by an ethanol content comparable to sorghum-based Tchapalo $(5.03 \pm 0.77 \mathrm{~g} / 100 \mathrm{~g})$ [11] [12], unlike Dolo $(2.3 \pm 0.25 \mathrm{~g} / 100 \mathrm{~g})$ [22]. In short, the Boumkaye acquires its characteristic properties from a relatively long aging (42 days), corresponding to a double fermentation. The same conclusions have been drawn from many empirical processes for the manufacture of traditional fermented beverages [12] [15] [22].

\section{Conclusion}

Boumkaye is a traditional fermented millet-based drink associated with an extract of the creepers of Abrus pulchellus, known for its numerous therapeutic virtues. This beverage has a maturation cycle linked to a double fermentation: lactic and alcoholic. Compared to a few local African beers, the Boumkaye is similar in its alcohol content, but its process was free of malting and brewing. This work provides a better knowledge of this traditional beer and paves the way for possible studies on the biotechnological role of Abrus pulchellus extract during storage. The optimization of each step of the process is necessary in order to increase the productivity and to improve the technological aspects of Boumkaye for a better use by producers.

\section{Acknowledgements}

We thank the AFBARD Company through Mrs Aida Coly Camara and Mr. Aba Bodian who allowed us to realize the diagnosis of the manufacturing process.

\section{References}

[1] Quin, P.J. (1959) Foods and Feeding Habits of the Pedi. Witwatersrand University Press, Johannesburg, 278.

[2] Monjerezi, M., Vogt, R.D., Aagaard, P. and Saka, J.D.K. (2011) Hydro-Geochemical Processes in an Area with Saline Groundwater in Lower Shire River Valley, Malawi: An Integrated Application of Hierarchical Cluster and Principal Component Analyses. Applied Geochemestry, 26, 1399-1413. https://doi.org/10.1016/j.apgeochem.2011.05.013

[3] Dahouenon-Ahoussi, E., Degnon, R.G., Adjou, E.S. and Sohounhloue, D.C. (2012) Stabilisation de la bière produite à partir de matières amylacées locales (Sorghum bicolor et Musa acuminata) par adjonction de l'huile essentielle de Cymbopogon citratus. Journal Applied Biosciences, 51, 3596-3607.

[4] Santiago-Urbina, J.A. and Ruíz-Terán, F. (2014) Microbiology and Biochemistry of Traditional Palm Wine Produced around the World. International Food Research Journal, 21, 1261-1269.

[5] Lemmens, R.H.M.J. and Breteler, F.J. (1999) Abrus fruticulosus Wight \& Arn, in Medicinal and Poisonous Plant. Backhuys Publisher, Kerkwerve, 76-77.

[6] Machana, S., Weerapreeyakul, N., Thitimetharoch, T. and Sripanidkulchai, B. (2010) Anticancer Activity Screening of Thai Medicinal Plants in Human Leukemic Cell Line MOLT-4. EJC Supplements, 8, 83-154.

https://doi.org/10.1016/S1359-6349(10)71391-4 
[7] Association Française Normalisation (1982) Produits dérivés des fruits et légumes jus de fruits, in Recueil de normes françaises des produits dérivés des fruits et légumes, jus de fruits. $1^{\text {th }}$ Edition, AFNOR, Paris, 327.

[8] Georgé, S., Brat, P., Alter, P. and Amiot, M.J. (2005) Rapid Determination of Polyphenols and Vitamin C in Plant-Derived Products. Journal Agriculture Food Chemestry, 53, 1370-1373. https://doi.org/10.1021/jf048396b

[9] Collin, S. and Crouzet, J. (2011) Polyphénols et procédés. Lavoisier, Paris, 326.

[10] Sawadogo-Lingani, H., Lei, V., Diawara, B., Nielsen, D.S., Moller, P.L., Traoré, A.S. and Jakobsen, M. (2007) The Biodiversity of Predominant Lactic Acid Bacteria in Dolo and Pito Wort, for Production of Sorghum Beer. Journal Applied Microbiolo$g y$, 103, 765-777. https://doi.org/10.1111/j.1365-2672.2007.03306.x

[11] Amane, N.D., Assidjo, N.E., Gbongue, M.A., Bohoussou, K. and Cardot, P. (2005) Caractérisation physico-chimique d'une bière traditionnelle ouest africaine: le Tchapalo. Agronomie Africaine, 17, 143-152.

[12] Aka, S., Djeni, N.T., N'guessan, K.F., Yao, K. C. and Dje, K. (2008) Variabilité des propriétés physico-chimiques et dénombrement de la flore fermentaire du tchapalo, une bière traditionnelle de sorgho en Côte d'Ivoire. Afrique Science, 4, 274-286.

[13] Thomas, K.C., Hynes, S.H. and Ingledew, W.M. (2002) Influence of Medium Buffering Capacity on Inhibition of Saccharomyces cerevisiae Growth by Acetic and Lactic Acids. Applied and Environmental Microbiology, 68, 1616-1623.

https://doi.org/10.1128/AEM.68.4.1616-1623.2002

[14] Torija, M.J., Beltran, G., Novo, M., Poblet, M., Rozes, N., Mas, A. and Guillamoä, J.M. (2003) Effect of Organic Acids and Nitrogen Source on Alcoholic Fermentation: Study of Their Buffering Capacity. Journal of Agricultural and Food Chemistry, 51, 916-922. https://doi.org/10.1021/jf020094r

[15] Valyasevi, R. and Rolle, R.S. (2002) An Overview of Small-Scale Food Fermentation Technologies in Developing Countries with Special Reference to Thailand: Scope for Their Improvement. International Journal Food Microbiology, 75, 231-239. https://doi.org/10.1016/S0168-1605(01)00711-5

[16] Parawira, W., Kudita, I., Nyandoroh, M.G. and Zvauya, R. (2005) A Study of Industrial Anaerobic Treatment of Opaque Beer Brewery Wastewater in a Tropical Climate using a Full-Scale UASB Reactor Seeded with Activated Sludge. Process Biochemestry, 40, 593-599. https://doi.org/10.1016/j.procbio.2004.01.036

[17] Kayodé, A., Hounhouigana, J.D. and Nout, M.J.R. (2007) Impact of Brewing Process Operations on Phyta, Phenolic Compounds and in Vitro Solubility of Iron and Zinc in Opaque Sorghum Beer. LWT Food Science and Technology, 40, 834-841. https://doi.org/10.1016/j.lwt.2006.04.001

[18] Blandino, A., Al-Aseeri, M.E., Pandiella, S.S., Cantero, D. and Webb, C. (2003) Cereal-Based Fermented Foods and Beverages. Food Research International, 36, 527-543. https://doi.org/10.1016/S0963-9969(03)00009-7

[19] Lestienne, I. (2004) Contribution à l'étude de la biodisponibilité du fer et du zinc dans le grain de mil et conditions d'amélioration dans les aliments de complément. PhD Dissertation, Université Montpellier II, Montpellier, 229.

[20] Lyumugabe, F., Uyisenga, J.P., Songa, E.B. and Thonart, P. (2014) Production of Traditional Sorghum Beer "Ikigagae" using Saccharomyces cerevisae, Lactobacillus fermentum and Issatckenkia orientalis as Starter Cultures. Food Nutrition Sciences, 5, 507-515. https://doi.org/10.4236/fns.2014.56060

[21] Aka-Gbezo, S., N'Guessan, F.K., Djeni, T.N., Djè, M.K. and Bonfoh, B. (2014) Partial Characterization of Bacteriocins from Two Pediococcus acidilactici Strains Iso- 
lated during Traditional Sorghum Beer Processing in Côte d'Ivoire. Advances in Microbiology, 4, 1250-1259. https://doi.org/10.4236/aim.2014.416135

[22] Maoura, N., Mbaiguinam, M., Gaillardin, C. and Pourquie, J. (2006) Suivi technique, analytique et microbiologique de la bili bili, bière traditionnelle tchadienne. Afrique Science, 2, 69-82. 